\title{
Traditional Fisheries of Antongil Bay, Madagascar
}

\author{
P. Doukakis', M. Jonahson'², V. Ramahery ${ }^{3}$, B.J. de Dieu Randriamanantsoa ${ }^{2}$ and S. Harding ${ }^{4}$ \\ ${ }^{I}$ Pew Institute for Ocean Science, University of Miami/RSMAS, 126 East $56^{\text {th }}$ Street, Mezzanine, New \\ York, New York 10022 USA; ${ }^{2}$ Wildlife Conservation Society, BP 8500 Soavimbahoaka, Antananarivo \\ 101, Madagascar; ${ }^{3}$ Blue Ventures, 52 Avenue Road, London, N6 5DR (in Madagascar office); ${ }^{4}$ Coral Cay \\ Conservation, Elizabeth House, 39 York Road, London SE1 7NJ, United Kingdom
}

Keywords: Traditional fisheries, Scombridae, Carangidae, beach seine, Antongil Bay. Madagascar

\begin{abstract}
Madagascar's marine fisheries provide revenue and sustenance for the island nation. Antongil Bay, the largest shallow-water bay along Madagascar's eastern coast, harbors significant marine resources and is heavily utilized by traditional, artisanal (shark-fin) and industrial fisheries. Mean hourly catch rates are just under $1 \mathrm{~kg} / \mathrm{hour} / \mathrm{fisher}$ and mean daily catch rates are $4.4 \mathrm{~kg} / \mathrm{day} / \mathrm{fisher}$. Beach seines, tamis (fine mesh seines), and combined use of gillnet and line were the most efficient gear types in terms of hourly and daily catch rates while gillnet and line were the most common gear types employed. Catch composition included 140 fish species from 69 families. Overall catch was dominated by species from Scombridae and Carangidae (Atule mate, Decapterus russelli, Megalaspis cordyla, Rastrilliger kanagurta). The Bay appears to be an important breeding habitat for scalloped hammerhead (Sphyrna lewini) and other species in the family Carcharhinidae. Given the multi-species and multi-sector nature of this fishery, ecosystem-
\end{abstract}

based management, wherein sensitive habitats are protected and limits are placed on destructive gear, is recommended, along with a zoning program to control resource-use overlap and encourage ownership.

\section{INTRODUCTION}

A threatened biodiversity hotspot, Madagascar has attracted conservation attention for decades (Myers 1988; Green \& Sussman 1990; Brooks et al. 2002; Benstead et al. 2003). As knowledge of Madagascar's marine biodiversity increases, so does the need for conservation, with the number of marine protected areas on the rise (McKenna \& Allen 2003; Cooke 2003).

Marine fisheries provide vital income and sustenance, valued at over US \$160 million annually (World Bank 2003). Export-driven, often foreign-owned tuna and shrimp fisheries account for most of the value, with the latter comprising $73 \%$ of total worth (World Bank 2003). Yet 70\% of overall production comes from small-scale fisheries, providing an important national protein source (World Bank 2003). Marine fisheries in Madagascar are not well-managed, with stocks considered fully exploited (FAO 1999, 2005). Given the global fisheries crisis, importance of fisheries to food security, and connection between availability of fish and terrestrial biodiversity conservation, greater attention to fisheries management in Madagascar and the developing world is needed (Brashares et al. 2004).

Antongil Bay is a large, productive shallowwater area on the eastern coast of Madagascar, providing seasonal habitat for humpback whales 
(Megaptera novaeangliae) and harboring marine protected areas (Rosenbaum et al.1997; Kremen $e$ al. 1999; Francis et al. 2002; Ersts \& Rosenbaum 2003). Herein we characterize the traditional fishery of the Bay.

Sheltered from the Indian Ocean by the Masoala peninsula, Antongil Bay is a $2,800 \mathrm{~km}^{2}$ semienclosed bay with maximum depths of $70 \mathrm{~m}$ (Figure 1). Nine major rivers and many small tributaries enter the Bay. Estuaries, seagrass beds, mangroves, and reefs can be found, with the latter occurring within marine protected areas (Figure 1). The watershed includes protected forests of Masoala National Park (PNM) and Makira and agricultural/ degraded areas (Figure 1). Air temperatures range from $26^{\circ} \mathrm{C}$ to $21^{\circ} \mathrm{C}$ and rainfall from $300-500$

\section{MATERIALS AND METHODS}

$\mathrm{mm} /$ month (December - August) to $75-150 \mathrm{~mm} /$ month (dry season), with annual values exceedin $2,000 \mathrm{~mm} /$ year.

Seven large and many smaller villages occur around the Bay, with fewer settlements on the eastern side due to the presence of the PNM and the absence of roads. Maroantsetra, the largest and wealthiest town, has the most diverse economy while smaller villages rely mostly on fishing and agriculture (rice, vanilla, cloves and coffee). Fishing complements agriculture, and while it does not provide a sole-source of income, fish is the primary source of protein. Transport and ecotourism are also economically important. Fishing includes a traditional fishery, conducted on-foot or from dug-out canoes (pirogues), an artisanal fishery, comprised of about six motorized vessels ( $25-50 \mathrm{hp}$ motorized vessels $<30 \mathrm{~m}$ length) targeting sharks for fin export, and a seasonal

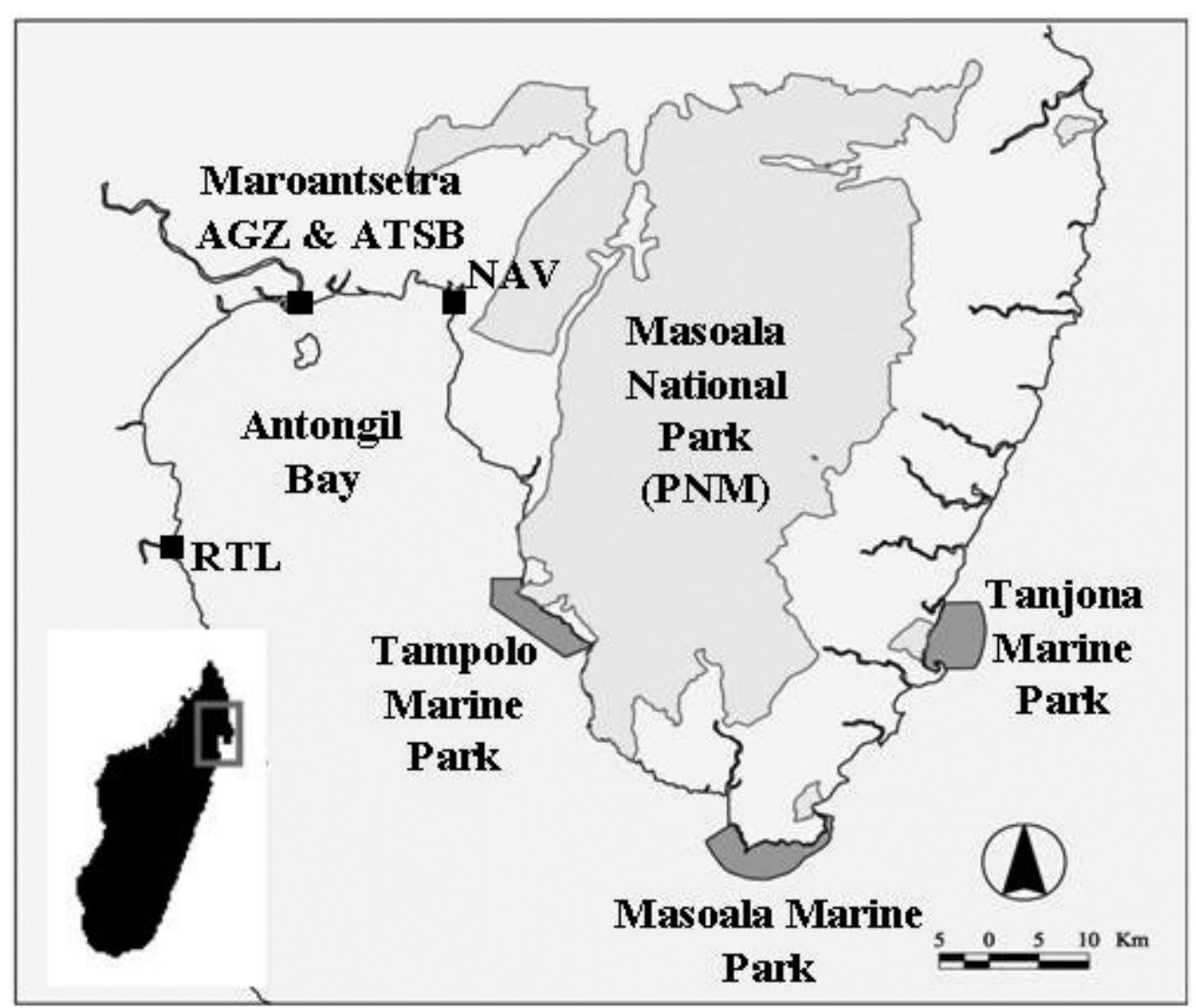

Fig. 1. Map of Madagascar and Antongil Bay illustrating Masoala National Park. Note: abbreviations denote landing site names as follows: Navana (NAV), Rantohely (RTL) and Maroantsetra (Andranonangozy (AGZ), Antsiranamborondolo (ATSB)) industrial fishery, performed by a maximum of five large trawling vessels targeting shrimp for export and finfish bycatch for export and national sale.

Informal community interviews and observations were conducted in 14 villages in 2000. Fisheries monitoring programs were the established in Navana (NAV), Rantohely (RTL) and Maroantsetra (landing sites Andranonangozy (AGZ), Antsiranamborondolo (ATSB)) between 2001 and 2003 (Figure 1). Villagers were trained in data recording and to examine and record the catch of 8-10 fishermen per day, 16 days per month. Total catch weight, weight by Malagasy name, fishing site, effort, gear, and total daily effort (number pirogues fishing) were recorded. Local Malagasy fish names were documented to family and/or species, with voucher specimens deposited at the American Museum of Natural History (AMNH, New York, USA). Hourly and daily CPUE comparisons between gear types were performed using nonparametric multiple comparisons in SPSS 15.0 for Windows.

\section{RESULTS}

Antongil Bay's traditional fishery is non-specific and non-target, with all non-poisonous, non-taboo species consumed. Gillnets, line, beach seines, tamis (small mesh seines of mosquito net or thin cloth), wooden seines and tidal traps ("vitry") and spearguns (not reported here) are used. No destructive fishing (poisons, dynamite) occurs. Fishing is conducted generally near the villages where fish are consumed, although markets in large towns (Maroantsetra, Rantohely, Masoala) are supplied by fishers from within and outside of the Bay. Fish not consumed immediately are dried, smoked and/or salted. Men and women of all ages fish, with women and small children using seine nets and traps on foot; men and older boys conduct pirogue-based fishing, and groups of men, women and children are involved in beach seining. Fishmongers are generally women and wives of fishermen.

Gillnets are the commonest gear used (of mean length $150 \mathrm{~m}$, range of $50-400 \mathrm{~m}, 1 \mathrm{~m}$ height and $2.5-5 \mathrm{~cm}$ mesh) followed by hook and line fishing. Average daily fishing effort was five hours (Table 1). Fishers using line and gillnet combined spent the most time fishing (Table 1). Mean catch rates for all sites and gears combined was just under $1 \mathrm{~kg} /$ hour/ fisher and $4.4 \mathrm{~kg} /$ day/fisher (Table 1). Significant differences $(\leq 0.05)$ were found among gear types for hourly and daily rates (Table 2 ). On average, 20 pirogues were active per day.

Catches included over 140 fish species from 69 families with over 225 local names (Table 3). Specimens of 81 species were preserved at the AMNH. Catches were dominated by species of Scombridae (47\%) and Carangidae (16\%). Rastrelliger kanagurta represented $38 \%$ of the total catch, Megalaspis cordyla, 7\%, and other small Carangids (Atule mate, Decapterus russelli), 9\%. Sharks, shrimp and marine mammals occur in the traditional catch. Small sharks are not directly targeted or valued (\$0.15-0.50 /individual). Catch

Table 1. Results of fisheries monitoring program in Antongil Bay, Madagascar. G: gillnet; L: line; V: Vitry (fence like structures made of wood or reeds); T: tamis (fine-mesh seine); G/L: gillnet and line combined; BS: beach sein

\begin{tabular}{lcccccccrrr}
\hline Gear & \multicolumn{1}{c}{ CPUE (kg/fisher/hour) } & \multicolumn{2}{c}{ CPUE (kg/fisher/day) } & \multicolumn{3}{c}{ Time (minutes) } \\
\cline { 2 - 11 } & $\begin{array}{c}\text { Mean } \\
\text { (Range) }\end{array}$ & SE & N & \multicolumn{1}{c}{$\begin{array}{c}\text { Mean } \\
\text { (Range) }\end{array}$} & SE & N & $\begin{array}{c}\text { Mean } \\
\text { (Range) }\end{array}$ & SE & N \\
& & & & & & & & & \\
\hline G & 0.83 & 0.018 & 3351 & 4.50 & 0.103 & 3404 & 306 & 2 & 3364 \\
L & 0.66 & 0.025 & 1245 & 3.45 & 0.166 & 1245 & 293 & 3 & 1215 \\
V & 0.81 & 0.057 & 77 & 3.80 & 0.401 & 78 & 270 & 12 & 77 \\
T & 2.41 & 0.418 & 38 & 7.10 & 0.983 & 38 & 204 & 12 & 38 \\
G/L & 1.53 & 0.296 & 62 & 10.91 & 2.203 & 64 & 416 & 13 & 63 \\
BS & 4.62 & 0.500 & 87 & 9.27 & 0.296 & 92 & 133 & 10 & 86 \\
All & 0.88 & 0.019 & 4865 & 4.43 & 0.094 & 4964 & 300 & 2 & 4843 \\
\hline
\end{tabular}


Table 2. Results of non-parametric multiple comparisons between CPUE for gear types and hours and daily catches (see Table 1 for abbreviations). Hourly rate comparisons above diagonal, daily rate comparisons below, with significant differences $(0.05)$ indicated $(*)$

\begin{tabular}{lcccccc}
\hline & $\mathbf{G}$ & $\mathbf{L}$ & $\mathbf{B S}$ & $\mathbf{V}$ & $\mathbf{G} / \mathbf{L}$ & $\mathbf{T}$ \\
\hline $\mathrm{G}$ & & $*$ & $*$ & - & - & $*$ \\
$\mathrm{~L}$ & $*$ & & $*$ & - & - & $*$ \\
$\mathrm{BS}$ & $*$ & $*$ & & $*$ & $*$ & $*$ \\
$\mathrm{~V}$ & - & - & $*$ & & - & $*$ \\
$\mathrm{G} / \mathrm{L}$ & $*$ & $*$ & - & $*$ & & - \\
$\mathrm{T}$ & - & $*$ & - & $*$ & - & \\
\hline
\end{tabular}

Table 3. Families of fish harvested in the Antongil Bay, Madagascar, traditional fishery listed in order of abundance (by weight). Multiple family names order of abundance (by weight). Multiple family names
are indicated when species within all families had been observed and the accuracy of monitor identification observed and the accuracy of monitor identification was uncertain. Species specific
from the author upon request

\section{Scombridae}

Carangidae

Anguillidae, Muraenesocidae, Muraenida

Anguillidae,
Sciaenidae

Mullidae

Mullidae

Atherinidae, Elopidae, Clupeidae

Aobiidae, Platycephalidae, Synodontidae

Ariidae

Ariidae
Serranidae

Carcharhinidae, Rhinobatidae Sphyrnidae

Menidae, Leiognathida

Gerreidae, Sparidae

Grichiuridae
Haemulidae

Belonidae, Hemiramphidae

Bothidae, Cynglossidae, Soleidae, Psettodidae

Siganidae

Terapontidae

Lutjanidae
Scaridae

Scaridae
Psettodidae

Psettodidae

Solynemidae

Nemipteridae,Holocentrida

Plotosidae

Pempheridae, Apogonidae

Chirocentridae

Ambassidae

Echeneidae

Echeneidae
Mugilidae

Mugilidae

Lethrinidae

\section{Acanthuridae}

Labridae

Balistidae, Diodontidae, Ostraciidae, Tetraodontidae

Scatophagidae

Rachycentridae
Caesionidae

Monodactylida

Dactylopteridae

Muraenidae

Scorpaenidae

Zanclidae

Kyphosidae

Kyphosidae
Aulostomidae

Liparidae

(1)

records contained 273 individual sharks (NAV $\mathrm{N}=62$ in 29 months; RTL N=211 in 13 months) of small size (mean TL $52.0 \mathrm{~cm} \pm 14.9 \mathrm{SD}$, range 13.5$97.0 \mathrm{~cm})$. Sharks identified by local name $(\mathrm{N}=203)$ consisted of species of non-hammerhead ( $\mathrm{N}=111$; mean TL $52 \mathrm{~cm} \pm 14.9 \mathrm{SD} 17.0 \mathrm{~cm}$, range 13.5-97.0 $\mathrm{cm}$ ) and hammerhead species identified as Sphyrna lewini $(\mathrm{N}=92$; mean TL $52 \mathrm{~cm} \pm 12.4 \mathrm{SD} 17.0 \mathrm{~cm}$, range $28.0-90.0 \mathrm{~cm}$ ). All non-hammerhead sharks were species of Carcharhinidae. Three specimens of Rhizoprionodon acutus were deposited in the AMNH collection $(40.0 \mathrm{~cm} \mathrm{TL})$. Hammerhead sharks were not captured at any site between July and September, while non-hammerhead sharks were captured only from June -December at RTL. Guitarfishes (Rhinobatos sp. Rhynchobatus djiddensis) also occur in the traditional catch. These fishes are not consumed due to local taboo. Interviews revealed that dugong (Dugong dugong), dolphins, and sea turtles are caught, the latter in catch reports at NAV. Shrimp occur in catches using beach seines and other gear.

\section{Discussion and Conclusion}

This study provides baseline catch data for the traditional fishery in Antongil Bay. The CPUE values observed are lower than those in reef fisheries elsewhere in Madagascar and in surrounding island fisheries (see Laroche \& Ramananarivo 1995) with hourly CPUE similar to that in São Tomé and Príncipe (d'Almeida et al. 1995). Using CPUE to gauge fishery health is difficult given the lack of comparative and baseline data, but the data will be useful for bio-economic modeling of the importance of fisheries to local populations (a protein, and for livelihoods), and for gauging future changes in fisheries health and the impacts of management. Comparisons of catch rates among gear types confirmed fisher's assumptions that beach seines yield higher catch rates than other gears. Expanded use of beach seines and other efficient gear (tamis) could significantly impact the fishery and ecosystem.

Antongil Bay appears to be a productive system with high biodiversity and important essentia habitat for marine resources. The main species occurring in the traditional fishery, Rastrelliger kanagurta and Decapterus russelli are small, planktivorous species common in coastal bays an plankton-rich waters, indicating the Bay is rich in primary productivity. Fisheries dependent and independent observation of estuarine seine fisheries in the northern part of the Bay indicate these area act as juvenile habitat for species occurring in the traditional fishery as adults (Ramahery 2004). The Bay further provides important habitat for sharks (e.g. Rhizoprionodon acutus and Sphyrna lewini) and guitarfish (Rhinobatos sp. Rhynchobatu djiddensis), with juveniles occurring in the traditiona fishery on a seasonal basis, and adults, sometimes gravid (e.g. Sphyrna lewini), harvested in the artisanal fishery (Doukakis, unpublished). Shark are increasingly threatened by the shark-fin fishery in the Bay and elsewhere in Madagascar (McVean et al. 2006). The Bay also harbors biodiversity beyond that described here as evidenced by catch in other fisheries sectors, including additional species and size classes of Lutjanidae and Scombridae, elasmobranchs (Family Carcharhinidae, Dasyatidae, Hemigaleidae, Myliobatidae, Rhinobatidae, Torpedinidae) (Doukakis, unpublished), coral ree fishes (Odendaal et al. 1995; in Cooke 2003), an a recently discovered new species of ponyfish (Photoplagios sp.; Sparks 2006).

The health of Antongil Bay's fisheries may be in decline, in part due to poor management. Fishers reported the need to travel farther, for longer, to acquire sufficient catch, decreased size of fish, and species composition changes. Fishers attributed the observed changes to the use of destructive gea (beach seines, small mesh seines), increased overal effort, and/or industrial fishing. The management of Antongil Bay fisheries is weak, with laws pertaining to fishery regulation (e.g. mesh size, marine mammal and turtle harvest prohibition) not enforced outside of marine protected areas and fisheries officials having limited capacity. Traditional fishers report abandoning practices such as throwing back undersized fish and joint net ownership because of decreasing catch, increased availability of inexpensive gear, and sharing of the fishery with other, unregulated actors.

Spatial and temporal overlap and interaction among fisheries sectors is a major management issue in Antongil Bay and Madagascar overall. A limited continental shelf causes industrial fishers to operate close to shore, with more than two-thirds of industrial shrimp trawler catch in Madagascar occurring within two miles of the coast (Gorez 2000). Although the industrial fishery targets shrimp, finfish by-catch is substantial (by-catch: shrimp ratio estimated at 7:1 to 17:1; Randrianarisoa et al. 2005). Low quality by-catch is sold to or collected by traditional fishers, with fishers forced into this practice by their own poor catch rates. Juvenile and adult shrimp harvest by traditional fishers produces conflict, potentially decreasing the productivity of industrial fisheries for shrimp in turn leading to increased industrial exploitation of finfish as shrimp catch declines. The ecological impacts of trawling are likely to be considerable (e.g. FAO 2001) and traditional fishing gear is often destroyed by industrial trawling. Efforts made during this study to engage the industria sector were unsuccessful but local NGO activity is currently focused on these issues. The 18 fisher organizations formed during our work provide an important social organization for addressing these issues.

Fisheries management in Antongil Bay should embrace a holistic ecosystem-based approach incorporating zoning to reduce overlap among sectors, protect essential, heavily exploited habitats and top predators, and reduce destructive gear and industrial trawler by-catch (Pikitch et al. 2004). The socio-economic impact of fisheries restrictions should be studied before management action is undertaken, particularly with respect to gender and age. Local populations wish to establish protected areas and restore mangroves degraded for charcoal production. Management must be 
sensitive to terrestrial and marine resource health connections and the potential for resource-use shift between these environments. Bay communities use both marine and terrestrial resources, sometimes simultaneously, so marine resource decline could threaten PNM, while reduction in agricultural land availability and productivity could increase the pressure on marine resources.

Acknowledgments-The following people provided input and support: George Amato, Barbara Brown, Demian Chapman, Andrew Cooke, Peter Ersts, Matthew Hatchwell, Liz Lauck, James MacKinnon, Tim McClanahan, Kenyon Mobley, Ellen K. Pikitch, Howard Rosenbaum, Mahmood Shivji, Malcolm Smale, W. Leo Smith, Melanie Stiassney. Funding was provided by the Pew Charitable Trusts and Wildlife Conservation Society.

\section{REFERENCES}

Benstead, J. P., De Rham, P. H., Gattolliat, J.-L., Gibon, F.-M., Loiselle, P. V., Sartori, M., Sparks, J. S. \& Stiassny, M. L. J. (2003) Conserving Madagascar's freshwater biodiversity. Bioscience 53(11): 1101-1111.

Brashares, J. S., Arcese, P., Sam, M. K., Coppolillo, P. B., Sinclair, A. R. E., \& Balmford, A. (2004) Bushmeat hunting, wildlife declines, and fish Bushmeat hunting, wildife declines, and fish
supply in West Africa. Science 306 (5699): 1180supply
1183.

Brooks, T. M., Mittermeier, R. A., Mittermeier, C. G., da Fonseca, G. A. B., Rylands, A. B., Konstant, W. R., Flick, P., Pilgrim, J., Oldfield, S., Magin, G. \& Hilton-Taylor, C. (2002). Habitat loss and extinction in the hotspots of biodiversity. Conserv. Biol. 16: 909-923.

Cooke A (2003) Marine and coastal ecosystems of Madagascar. In: Goodman, S. M. \& Benstead, J. P. (eds) The Natural History of Madagascar. $1728 \mathrm{p}$.

d'Almeida, A. D., Anibal, O., de Barros Bandiera, A. Costa, G., Texeira M. \& Worms, J. (1995) Marin Resource Evaluation Project. Small scale fishery in São Tomé Results from there jears of reseach. Fis Fishery Direction, Dep Rep Fishery, Democr Príncipe

Ersts, P. J. \& Rosenbaum, H. C. (2003) Habita preference reflects social organization of humpback whales (Megaptera novaeangliae) on a wintering ground. J. Zool. 260: 337-345.

FAO (1999) Fishery Country Profile, The Republic of Madagascar.

FAO (2001) Tropical shrimp fisheries and their impact on living resources. Shrimp fisheries in Asia: Bangladesh, Indonesia and the Philippines; in the Near East: Bahrain and Iran; in Africa: Cameroon, Nigeria and the United Republic of Tanzania; in Latin America: Colombia, Costa Rica, Cuba, Trinidad and Tobago, and Venezuela. FAO Fisheries Circular. No. 974. Rome, FAO. 2001. 378p.

FAO (2005) Review of the state of world marine fishery resources. FAO Fisheries Technical Paper. No. 457. Rome, FAO. 2005. 235p.

Francis, J., Nilsson A., \& Waruinge D. (2002) Marine protected areas in the eastern African region: how successful are they? Ambio 31(7-8): 503-511.

Green, G. M. \& Sussman, R. W. (1990) Deforestation history of the eastern rain forests of Madagasca from satellite images. Science 247: 212-215.

Gorez, B. (2000) Pink gold, muddy waters. Samudra 25: 27-30.

Kremen, C., Razafimahatratra, V. Guillery R. P., Rakotomalala, J., Weiss, A. \& Ratsisompatrarivo, J.-S. (1999) Designing the Masoala National Park in Madagascar based on biological and socioeconomic data. Conserv Biol. 13(5): 10551068.

Laroche, J. \& Ramananarivo, N. (1995) A preliminary survey of the artisanal fishery on coral reefs of the survey of the artisanal fishery on coral reefs of the
Tulear Region (southwest Madagascar). Coral Reefs 14: 193-200.

McKenna, S.A. \& Allen, G.R (eds). 2003. A Rapid Marine Biodiversity Assessment of Northwest Madagascar. Bulletin of the Rapid Assessment Program 31, Conservation International, Washington, DC

McVean, A. R, Walker, R. C. J, Fanning, E (2006) The traditional shark fisheries of southwest Madagascar: A study in the Toliara region. Fisheries Research 82: 280-289.

Myers, N. (1988) Threatened biotas: hotspots: in tropical forests. The Environmentalist 8: 1-20.

Odendaal, F. J., Kroese, M., Jaomanana (1995) The strategic plan for the management of the coastal ztrate of the Hasola Peninsula, Madagasear. Mace zon-Africa Environmental Consultants, Cape Town, South
Africa. Africa.

Pikitch, E. K., Santora, C., Babcock, E. A., Bakun, A., Bonfil, R., Conover, D. O., Dayton, P., Doukakis, P., Fluharty, D., Heneman, B., Houde, E. D., Link, J., Livingston, P. A., Mangel, M., McAllister, M. K., Pope, J., \& Sainsbury, K. J. (2004) Ecosystem-based fishery management. Science 305: 346-347.

Ramahery, V. (2004) Etude de la faune ichtyologique de l'estuaire de Masindrano, Baie d'Antongil, Madagascar. Memoire de DEA. Universite d'Antananarivo, Madagascar.

Randrianarisoa, L. N., Lavatra, T. \& Rabenevanana M. W. (2005) Trawler Ichthyofauna in Madagasca Shrimp Fisheries: Catch and General Characteristics in Antongil Bay, Madagascar. Unpublished paper presented at the $4^{\text {th }}$ WIOMSA Marine Science Symposium, Mauritius, September 2005

Rosenbaum, H. C., Walsh, P. D., Razafindrakoto, Y., Vely, M. \& DeSalle, R. (1997) First description of a humpback whale breeding ground in the Baie D’Antongil, Madagascar. Conserv. Biol. 11: 312-314.

Sparks, J. S. (2006) A new species of ponyfish (Teleostei: Leiognathidae: Photoplagios) from Madagascar, with a phylogeny for Photoplagio and comments on the status of Equula lineolat Valenciennes. American Museum Novitates $\mathbf{3 5 2 6}$ 1-20.

World Bank (2003) Madagascar Rural and Environment Sector Review. Report No. 26106-MG. 